Arhe XVII, 33/2020

UDK 364.2:37

141.22

1 Schopenhauer A.

1 Nietzsche $F$.

DOI https://doi.org/10.19090/arhe.2020.33.243-265

Pregledni rad

Overview Article

\author{
IVICA KELAM ${ }^{1}$, LUKA RAŠIĆ ${ }^{2}$ \\ University of Josip Juraj Strossmayer in Osijek, Faculty of \\ Education, Croatia
}

\title{
THE INFLUENCE OF SCHOPENHAUER'S AND NIETZSCHE'S PHILOSOPHICAL THOUGHTS ON THE PHILOSOPHY OF EDUCATION AND EDUCATIONAL PESSIMISM
}

\begin{abstract}
This paper gives a particular overview of reflections on education by two renowned philosophers of West European culture, Arthur Schopenhauer and Friedrich Nietzsche. What links their philosophy of education is the inclination towards the more complete shaping of a man. Nietzsche is a great supporter of Schopenhauer's understanding of philosophy as a philosophy of life. However, while Schopenhauer remained imprisoned in the world of pessimism, Nietzsche overcame the pessimistic view of the world with the image of a creative artist who consistently sets his life in motion, while enjoying his art of living. The thing they have in common is extreme individualism - the understanding of philosophy as the liberation of inner life. Arthur Schopenhauer perceived a man as a being of will that succumbs to laws of nature and the lower levels of humanity - will and passion. Friedrich Nietzsche saw a man as a being of will for power, emphasizing the power of the urgent and irrational one. Schopenhauer gave the pessimistic view of a man who is under the power of an unquenchable lust for life, whereas Nietzsche gave a nihilistic view of the world, in which he advocated demolishing and putting an end to the old values. In Nietzsche's
\end{abstract}

${ }^{1}$ Author's e-mail address: kelamivica@ gmail.com

2 Author's e-mail address: luka.rasic.031@gmail.com 
opinion, a nihilist is someone who sees everything as pointless and futile. Arthur Schopenhauer had a significant influence, not only on Friedrich Nietzsche but also on some other great men of his time, who mostly did not support his philosophy in its entirety. Understanding the world in Schopenhauer's way came to life at the end of the 19th century and later, primarily because of Friedrich Nietzsche. This was an era in which social sciences finally began to develop separately, but at the same time complement each other. Due to this interaction, it was possible for Schopenhauer, and through him also for Nietzsche, to have such a significant influence on the European spiritual life.

Keywords: philosophy, education, education pessimism, Arthur Schopenhauer, Friedrich Nietzsche

\section{INTRODUCTION}

In order for a person to satisfy his basic existential needs (biological, physical, psychological, social, spiritual, etc.), he must be enabled to be educated so that he can develop all his abilities and potentials, above all intellectual and moral abilities. The issue of education is as old as our Western culture. Throughout history, many philosophers have dealt with this issue because it is of the utmost importance to both the individual and society. Arthur Schopenhauer, known as the "philosopher of pessimism", is one of the most influential figures in philosophy when talking about the phenomenon of human education. Arthur Schopenhauer and Friedrich Nietzsche share the same philosophical thought, at least as far as Nietzsche's initial work is concerned, which is imbued with the constant pessimism and meaninglessness of human existence. Later, Nietzsche distanced himself from Schopenhauer's philosophical doctrine but was constantly in various ways in dialogue with his predecessor. Their philosophy was ahead of the time in which they lived. With their original views, they have opened up some important topics that are still debated today. The paper consists of two parts. In the first part, we will briefly introduce the main philosophical thoughts of Arthur Schopenhauer's philosophy and their influence on Friedrich Nietzsche. In the second part, we will highlight some crucial determinants of the philosophy of education and point out 
the contemporary efforts and opportunities in education with particular emphasis on the problem of educational pessimism

\section{A BRIEF REVIEW OF SOME OF SCHOPENHAUER'S PHILOSOPHICAL THOUGHTS}

The German philosopher Arthur Schopenhauer (1788-1860) is considered the founder of metaphysical pessimism. He was a philosopher who hated the world, despised people, and denied the will to live. Due to his hypersensitive nature, he often came into conflict with people, so he preferred to live alone. Socially maladapted, Schopenhauer led a solitary life, devoting himself to the study of Greek and Roman classics, but also to Indian philosophy, for which he retained an interest until the end of his life.

$\mathrm{He}$ is the author of the book The World as Will and Representation, which has become his most famous and significant work - a philosophical classic. In this work, he outlined his philosophy. As the basis of his philosophy, he laid down the subjective-idealistic thesis of the world as subjective human ideas.

For Schopenhauer, "metaphysical pessimism in the sense that he portrays it as a consequence of the nature of metaphysical will. Whatever it is, we must view the phenomenal reality in the black light of how we perceive it. We can also do something to ease this suffering, but we cannot change the basic character of the world or human life. If, for example, the war were to end, if all the aspirations were satisfied, then there would be a state of unbearable boredom that would give birth again to conflict. In any case, the overcoming of suffering and evil in the world has its last root in the nature of things per se."

Furthermore, Batovanja claims that "Schopenhauer is a specialist in the darker sides of human existence. The world is hell and life is suffering. Pessimism is the only proper perspective on the world and

${ }^{3}$ Udruga za promicanje filozofije Filozofija.org, Arthur Schopenhauer (1788. 1860.), https://www.filozofija.org/wp-content/uploads/Povijest_fil.org/suvremena_ 1_pdf/Schopenhauer-final.pdf, accessed 10. february 2020. 
life." ${ }^{4}$ For Schopenhauer, only one metaphenomenal reality or thing per se is possible, and that is the will. Will represents the urge to live. All living and inanimate nature represent the struggle and the urge to survive. Will is a metaphysical category and as a matter in itself, is unprovable. We cannot recognize her, but we recognize her by her appearance - man. Therefore, Sunajko claims, "life, which is the will to live, causes suffering in the individual because he has to endure his entire character of will throughout his life. Only a posteriori, by experience, does a man realize to his amazement that he is not free, but that he is subordinate to necessity, that - despite all his thoughts and thoughts - he does not change his actions, and that he has to endure, throughout his life, the character that he incites and so on role assumed play till the end. Schopenhauer calls the submission of the character of the will pessimistic." The essential line of metaphysical will is an enduring aspiration. She can never be completely satisfied. Aspiration, as an expression of need, is a form of pain. When we achieve some aspiration, we feel boredom. So a man's life is just a shift of pain and boredom. That is why this world, as the objectification of a metaphysical supraindividual will, is, according to Schopenhauer, the worst of all possible worlds, and necessary experience of suffering marks life under the dictates of that will. Therefore "the only thing that can kill the will that always manifests itself in time and space is cognition, and it comes so that the awareness of other objects is so potent that the consciousness of ourselves that we are always equated with will disappear. Therefore, a change is needed in the subject, which by cognition, is detached from its own will, which means that it does not perceive the world of things by spatio-temporal appearance but by intuitive ripening. Only then is the moment of the superiority of the intellect over the will."

Schopenhauer says in his philosophy that the world has a moral meaning. The will to live is manifested in egoism, self-affirmation,

4 Vesna Batovanja, „Škola filozofa“, Studia lexicographica: časopis za leksikografiju i enciklopedistiku, vol. 8, no. 1(14), 2014., pp. 144.

${ }^{5}$ Goran Sunajko, „Genij nasuprot talentu - umjetnost nasuprot estetici: bit Schopenhauerove estetike“, Studia lexicographica: časopis za leksikografiju i enciklopedistiku, vol. 11, no. 21, 2017., pp. 63.

${ }^{6}$ Ibid. pp. 65. 
hatred, and conflict, which is the source of evil and cruelty. That is why morality, if at all possible, must involve the annulment of the will to live. If a man is an objectification of that will, that annulment becomes selfabasement and asceticism. For Schopenhauer, suicide is not a moral act because it is a hidden pursuit of life for him. "Suicide kills an appearance (a particular individual), but the will persists, in species and gender. $\mathrm{He}$ thus does not abandon the will to live, but only to live."7 Therefore, Schopenhauer concludes that "a suicide man wants a life and is dissatisfied only with the conditions under which he is given." 8

Numerous philosophers and writers have found inspiration in Schopenhauer's philosophy of extreme pessimism. Schopenhauer significantly influenced the development of modern aesthetics as well as the general artistic trends of the 20th century. Arthur Schopenhauer considered himself a radical pessimist because he emphasized the illusory nature of human happiness and the inevitability of suffering. Schopenhauer sees this world as the worst possible. According to him, if the world were only a little worse, he could not exist at all. That is why he finds solace and oblivion for human suffering and horrors in art. In this context, Frelih writes, "by giving art the healing power of overcoming the entire suffering of human existence, but also the power to respond specifically to life's questions and, therefore, to contain primordial wisdom, Schopenhauer has struck the foundations of the aesthetics we know today.",

For the first time, Schopenhauer distinguishes aesthetics as a distinct philosophical branch and even places it at the very center of philosophical inquiry.

Furthermore, Frelih emphasizes Schopenhauer's role in changing the understanding of art and argues that "the second half of the 19th century changed the view and understanding of art by European intellectuals. Until then, art was seen as a certain aesthetic addition to life

\footnotetext{
${ }^{7}$ Ibid pp. 64

${ }^{8}$ Arthur Schopenhauer, Sämtliche Werke, Paul Deussen (ed.), München 1911., pp. 471.

9 Jasenka Frelih, „Utjecaj Arthura Schopenhauera na književnost i umjetnost“, Nova prisutnost: časopis za intelektualna i duhovna pitanja,vol. XI, no. 1, 2013., pp. 59.
} 
and as entertainment for the sake of beauty. Schopenhauer, through his reflection on art, has made art now viewed as a way of life. Schopenhauer believed that art was a kind of cognition that made it possible to grasp the inner nature of things, as opposed to modern science, which allowed us to grasp obvious things, most often misunderstood and rejected."10 Schopenhauer was the first philosopher to give healing power to art, and he associates the artist with the genius most often misunderstood and rejected.

Schopenhauer's relation between aesthetics as a subject and art as an object of study of aesthetics is distinguished by the difference of talent conditioned by space and time from the genius that transcends space and time. Schopenhauer says talent transcends the workability of the average, but not their power of understanding, while genius transcends both. Furthermore, Sunajko states, "he defines Genius Schopenhauer as one in whom there is a higher power of intellect than will (...) Genius rests on ideas, while talent rests on the sensory objection of the reflection of the world, which is always reflected as the appearance of will in time and space (...) The advantage of talent lies in its exceptional skill and pervasiveness of discursive rather than perceptual cognition (...) Genius adorns the perceptual perception of the world as a phenomenon, as a fantasy, and his thinking is manifested in images (...) Therefore, the difference between genius and talent lies in the distance from the will most of all in genius (...) Genius is his imagery, poems, and thoughts the goal, while talent is a means. Talents adhere to contemporaries and are ready to serve their needs and moods.

For this reason, they most often live in good conditions, while the position of genius is often unfortunate. Genius mostly lives alone. $\mathrm{He}$ sacrifices his personal well-being for an objective goal (...) The work of a genius is for all time, it is timeless (...) Recognition gives him only posterity, while talents live and die with their time (...) Talent is part of this world, and he is just better than others. Genius, though part of this world, finds itself in a world that is yet to come. It is, therefore, immeasurable and incomparable because the existing world measures do

${ }^{10}$ Ibid, pp. 68. 
not apply to it." ${ }^{\prime 1}$ The genius is not an innate characteristic. As with talent, the only predisposition is innate. Genius develops throughout life through tireless work on itself and in a specific area of interest. A genius is obsessed with the eternal pursuit of perfection.

By its very nature, genius does not crave attention and popularity. He realized his ingenuity and did not need any confirmation from her. Social status is not what determines him, nor will he ever be more important to him than his pursuit of perfection.

\section{SCHOPENHAUER'S INFLUENCE ON NIETZSCHE}

Friedrich Nietzsche (1844-1900), who, at the age of 21, became acquainted with Schopenhauer's work, was sharply drawn to his thoughts. Schopenhauer's position on the relation of will and mind had a significant influence on Nietzsche. According to Schopenhauer, the primary is not the mind, intelligence, spirit, but instincts, desires, and passions. "The basis of the psychic is the will to live. Mind, intellect and spirit spring from this will. He described the relation of will and intellect with a metaphor: the will is the master of the house, and the intellect is its servant and slave." 12

For Nietzsche, the world is just a will for power and nothing else. It is just an application of Schopenhauer's stance on the will to exist or to live. For Nietzsche, the basis of life is manifested in instinct, which in turn is power. He perceives power as the intrinsic quality of the individual. Nietzsche is particularly delighted with Schopenhauer's uncompromising search for truth. In order to find the key to reality, according to Schopenhauer, we must look within ourselves, since it is precisely in the inner consciousness or in the inner perception - a kind of self-observation - that the path to the truth lies. In Nietzsche's world, society and the individual are opposed. Against modern society, Nietzsche felt contempt because it imposes false imperatives of happiness, not internal ones. Nietzsche states: "As long as anyone desires

11 G. Sunajko, Genij nasuprot talentu - umjetnost nasuprot estetici: bit Schopenhauerove estetike, pp. 70-73.

${ }^{12}$ V. Batovanja, Škola filozofa, pp. 145. 
life as he desires happiness, he has not yet raised his eyes above the horizon of the animal, for he only desires more consciously what the animal seeks through blind impulse. But that is what we all do for the greater part of our lives: usually we fail to emerge out of animality, we ourselves are the animals whose suffering seems to be senseless." 13

Schopenhauer's pessimism was a source of inspiration for Friedrich Nietzsche. In the essay Schopenhauer as Educator, Nietzsche describes his relation to Schopenhauer's philosophy and presents the spiritual crisis of 19th-century civil society, highlighting the difference between philosophy as a theory and the philosophy of life. Encouraged by the attitude of the then society towards the sciences, Nietzsche questions whether life should be governed by science, or whether science should govern daily life. At the end of the 19th century and the turn of the 20th century, knowledge and science dominated, and empirical sciences cannot offer answers to these questions. It is evident that the situation has not changed today, and even today empirical sciences are being put on the pedestal, the STEM revolution in schools and society is required, and Nietzsche offers philosophy in response. ${ }^{14}$

According to Nietzsche, therefore, only philosophy remains, but not that taught by university professors because it is rigorously conducted by the university, but only by free thinkers who are entirely free from both the onslaught of intellectual uplift and the onslaught of social norms. In this ideal of philosophers, Nietzsche saw the creator of new values, who must be critical, but more than that: he must be a destroyer in order to be a creator, stating: "Let the philosophers grow untended, deny them all prospect of place and position within the bourgeois professions, cease to entice them with salaries, more, persecute them, show them disfavour you will behold miracles! The poor seeming philosophers will flee apart and seek a roof wherever they can find it; one will become a parson, another a schoolmaster, a third will creep into the shelter of an editorial

13 Friedrich Nietzsche, Untimely Meditations, Cambridge University Press, Cambridge 1997., pp. 157-158.

${ }_{14}$ Ivica Kelam, Jasmina Sagadin Vučić, „The Applicability of the Socrates Method of Education in Education Today“, Pannoniana, Vol. 3, No 1-2, 2019. pp. 137-167. 
job on a newspaper, a fourth will write instruction manuals for girls' high schools, the most sensible of them will take up the plough and the vainest will go to court. Suddenly it will all be empty, everyone will have flown the nest: for it is easy to get rid of bad philosophers, one only has to cease rewarding them. And that is in any event more advisable than for the state publicly to patronize any philosophy, whichever it may be." 15 Nietzsche sees the true philosopher as a creator and a hero, and philosophy as the only asylum that no tyranny of the world can reach.

In the essay Schopenhauer as Educator, Nietzsche very critically values contemporary German culture and the state. Most of it is fiercely contested in the education and science system. Nietzsche believes that the desire for knowledge depends on the desire for power. The meaning of knowledge is not in grasping the absolute truth, but in managing it.

Nietzsche further states: "If, however, a man should arise who really gave the impression of intending to apply the seal pel of truth to all things, including the body of the state, then the state would, since it affirms its own existence before all else, be justified in expelling such a man and treating him as an enemy: just as it expels and treats as an enemy a religion which sets itself above the state and desires to be its judge. So if anyone is to tolerate being a philosopher in the employ of the state, he will also have to tolerate being regarded as having abandoned any attempt to pursue truth into all its hideouts. At the very least he is obliged, so long as he is the recipient of favours and offices, to recognize something as being higher than truth, namely the state. And not merely the state but at the same time everything the state considers necessary for its wellbeing: a certain form of religion, for example, or of social order, or of army regulations - a noli me tangere is inscribed upon everything of this sort. Can a university philosopher ever have realized to the full the whole gamut of duties and limitations imposed upon him? I do not know; if he has done so and has nonetheless remained an official of the state he has been a bad friend of truth; if he has never done so - well, I would say he would still be no friend of truth.",16

\footnotetext{
${ }^{15}$ F. Nietzsche, Untimely Meditations, pp. 190.

${ }^{16}$ Ibid. pp. 185.
} 
Nietzsche sharpens his stance and says: "the state never has any use for truth as such, but only for truth which is useful to it, more precisely for anything whatever useful to it whether it be truth, half-truth or error. A union of state and philosophy can therefore make sense only if philosophy can promise to be unconditionally useful to the state, that is to say, to set usefulness to the state higher than truth. It would of course be splendid for the state if it also had truth in its pay and service; but the state itself well knows that it is part of the essence of truth that it never accepts pay or stands in anyone's service. Thus what the state has is only false 'truth', a person in a mask; and unfortunately this cannot do for it what it so much desires genuine truth to do: validate and sanctify it." ${ }^{17}$ In the society in which he lived, Nietzsche noticed a tendency toward a faster and more pragmatic education. Especially, the goals of education were reduced to the benefit and the highest possible monetary gain. In this context, Nietzsche claims: "however loudly the state may proclaim its service to culture, it furthers culture in order to further itself and cannot conceive of a goal higher than its own welfare and continued existence. What the money-makers really want when they ceaselessly demand instruction and education is in the last resort precisely money. When those who require form ascribe to themselves the actual labour on behalf of culture and opine, for instance, that all art belongs to them and must stand in the service of their requirements, what is quite clear is that by affirming culture they are merely affirming themselves: that they too are therefore still involved in a misunderstanding. “ 18

Nietzsche emphasizes the need for a new type of cultural-focused institution, noting that the highest values are devalued. For him, the highest values are the good, the true, the beautiful, and the sacred, which gives meaning to human existence. Given the deep depression caused by the modern existence of devoid of value, Nietzsche saw the immediate task of setting new values. Removing the "real" world can encourage the creation of new values and give new meaning to existence.

Nietzsche despises civil servants, all those who subordinate culture to institutions, hates the selfishness of entrepreneurs and the

\footnotetext{
${ }^{17}$ Ibid. pp. 190-191.

${ }^{18}$ Ibid. pp. 174.
} 
egoism of the state. He believes in a culture that will be created only by creative philosophers and artists, who will complete nature and not bury that same culture in the name of society. According to Nietzsche, only selected individuals can take on this task: "here I have arrived at an answer to the question whether it is possible to pursue the great ideal of the Schopenhauerean man by means of a practical activity. One thing above all is certain: these new duties are not the duties of a solitary; on the contrary, they set one in the midst of a mighty community held together, not by external forms and regulations, but by a fundamental idea. It is the fundamental idea of culture, insofar as it sets for each one of us but one task: to promote the production of the philosopher the artist and the saint within us and without us and thereby to work at the perfecting of nature. For, as nature needs the philosopher, so does it need the artist, for the achievement of a metaphysical goal, that of its own selfenlightenment, so that it may at last behold as a clear and finished picture that which it could see only obscurely in the agitation of its evolution for the end, that is to say, of self-knowledge." ${ }^{19}$ For Nietzsche, the artist is the same as for Schopenhauer, that is, a lone individual, rejected from the world simply because he is different and sees the world more thoroughly than other people. A typical example of such an artist for Nietzsche is precisely Schopenhauer about which he writes the following: ,the artist creates his work according to the will of nature for the good of other men: that is indisputable; nonetheless he knows that none of these other men will ever love and understand his work as he loves and understands it. Thus this greater degree of love and understanding is, given the ineptitude of nature, required for the production of a smaller degree; the greater and nobler is employed as a means of producing the lesser and ignoble." 20

The philosophy of education is closely related to the philosophy of politics. The state is one of the main factors when it comes to designing and realizing education. Nietzsche's philosophy of education emerges in response to state constraints and control over the university's activities and the state's aspiration to determine the cultural and

${ }^{19}$ Ibid. pp. 160.
${ }^{20}$ Ibid. pp. 178. 
educational priorities that the university should act upon. Nietzsche describes the current situation of his time as follows: "the sciences, pursued without any restraint and in a spirit of the blindest laissez faire, are shattering and dissolving all firmly held belief; the educated classes and states are being swept along by a hugely contemptible money economy. The world has never been more worldly, never poorer in love and goodness. The educated classes are no longer lighthouses or refuges in the midst of this turmoil of secularization; they themselves grow daily more restless, thoughtless and loveless. Everything, contemporary art and science included, serves the coming barbarism. The cultured man has degenerated to the greatest enemy of culture, for he wants lyingly to deny the existence of the universal sickness and thus obstructs the physicians. ${ }^{21}$ There are rare times when a 21 st-century man can admit to himself that he is "his own man". The modern man is afraid to think, mostly because of fear of condemnation of other people. The situation was similar at the time of Nietzsche, where the man was primarily afraid of responsibility, which might have been imposed on him if he expressed his position. The institutions taught in Nietzsche's time, and still is today, that you must obey to the state, and not to yourself, as Nietzsche insisted when he wrote: „but what is it that constrains the individual to fear his neighbour, to think and act like a member of a herd, and to have no joy in himself? Modesty, perhaps, in a few rare cases. With the great majority it is indolence, inertia, in short that tendency to laziness of which the traveller spoke. He is right: men are even lazier than they are timid, and fear most of all the inconveniences with which unconditional honesty and nakedness would burden them. (...) When the great thinker despises mankind, he despises its laziness: for it is on account of their laziness that men seem like factory products, things of no consequence and unworthy to be associated with or instructed. The man who does not wish to belong to the mass needs only to cease taking himself easily; let him follow his conscience, which calls to him: 'Be your self! All you are now doing, thinking, desiring, is not you yourself'.",22

\footnotetext{
${ }^{21}$ Ibid. pp. 148-149.

${ }^{22}$ Ibid. pp. 127.
} 
It seems as if one deliberately lags behind in their education process. Judging by Nietzsche, man has built institutions that compel him to abandon his true mission in life, and works artfully to maintain the institutions. Institutions have tarnished man's thought and honesty. Therefore, man is called to seek a suitable educator who, through his philosophy of life - which defies the limitations of tradition, society and time - will teach him to truly think, speak and write because: "your true educators and formative teachers reveal to you that the true, original meaning and basic stuff of your nature is something completely incapable of being educated or formed and is in any case something difficult of access, bound and paralysed; your educators can be only your liberators." ${ }^{23}$ That is the secret of any education according to Nietzsche. Because what is learning, if not one type of liberation of man. According to Nietzsche, we are not worthy of expressing our opinions or views because they are scrambled. That is why we must follow Arthur Schopenhauer's views, which are only correct. It is Nietzsche who elevates him as a true educator as opposed to university professors of philosophy "the extent that they make philosophy itself ludicrous." "24

Nietzsche sharpens his stance with the words: "the only critique of a philosophy that is possible and that proves something, namely trying to see whether one can live in accordance with it, has never been taught at universities: all that has ever been taught is a critique of words by means of other words. And now imagine a youthful head, not very experienced in living, in which fifty systems in the form of words and fifty critiques of them are preserved side-by-side and intermingled - what a desert, what a return to barbarism, what a mockery of an education in philosophy! But of course it is admittedly no such thing; it is a training in passing philosophical examinations, the usual outcome of which is well known to be that the youth to be tested - tested all too severely, alas! - admits to himself with a sigh of relief: "Thank God I am no philosopher, but a Christian and a citizen of my country'!"25

\footnotetext{
${ }^{23}$ Ibid. pp. 129.

${ }^{24}$ Ibid. pp. 190.

${ }^{25}$ Ibid. pp. 187.
} 
Nietzsche admires Schopenhauer, who, instead of social comfort, accepted isolation as the only oasis of freedom. He introduces him as a revivalist of German culture and German university philosophy. He had just selected Schopenhauer as the supreme educator so that his ideas and attitudes would bring man back to philosophy because he had strayed from it.

In this regard, Nietzsche says of Schopenhauer: "experience unfortunately teaches us better - or rather, worse: it tells us that nothing stands so much in the way of the production and propagation of the great philosopher by nature as does the bad philosopher who works for the state. A painful fact, is it not? recognizably the same as that to which Schopenhauer first directed attention in his celebrated treatise on university philosophy. I shall return to it later: for one has to compel men to take it seriously, that is to say to let it inspire them to action, and I consider every word behind which there does not stand such a challenge to action to have been written in vain; and it is in any event a good thing again to demonstrate the truth of Schopenhauer's always valid propositions, and to do so by direct reference to our closest contemporaries, since a well-disposed man might think that since he launched his accusations everything has taken a turn for the better in Germany. Even on this point, minor though it is, his work is not yet done. ${ }^{26} \mathrm{We}$ can conclude that Nietzsche's basic idea of education is contained in the view that one should fully develop one's intellectual and creative abilities, rather than form them externally according to a predetermined model. The correct development of education requires independence from state control.

\section{A FEW THOUGHTS ON THE PHILOSOPHY OF EDUCATION TODAY}

Philosophy of education is an interdisciplinary pedagogical and philosophical field that considers the concept of man as an object of education, the meaning, and purpose of education, the relation between culture and education, the educational ideal, educational values, etc.

${ }^{26}$ Ibid. pp. 184. 
The goal of the philosophy of education is the complete realization of the person, placing a particular emphasis on intellectual and moral upbringing. Aleksandra Golubović states: "in the philosophy of education, we are talking about two types of abilities that a person needs to develop and perfect, which are innate and acquired. The philosophy of education deals with the latter kind, that is, the possibility of forming certain character traits. In this sense, the activity and process of education refer to the acquisition of those abilities or character traits that are desirable for the educator (whether it is attempted to be perfected by the parent, professor, or the educator himself)." ${ }^{27}$ Golubović further points out: "education is the ultimate goal of the educational process. The fulfillment of this goal signifies that the man has fully realized himself (that he has developed and perfected all his potentials and become a fully grown person).

Moreover, this can only be achieved if he is raised in the first place to be a person (i.e., an individual), and only then he or she is a member of society or a member of a particular state (...) In a sense, it can be said that the goal of education is a permanent opportunity for development. $" 28$

Philosophy of education is not dealt with solely by philosophers. Different experts (philosophers, pedagogues, psychologists, etc.) have different approaches to educational activity. Some experts believe that educational action is almost undesirable because it would be a direct encroachment on a person's character, and the question is who has the right to interfere. In any case, they will all agree on the fact that the philosophy of education is a discipline that questions the essence of education, and education is an activity that develops man's powers.

Since we live in a society where new knowledge is being discovered day by day, education is mainly focused on their research and evaluation. Therefore, in education today, the emphasis is mainly placed on the development and improvement of intellectual abilities, and the educational component is somewhat neglected, as Golubović also testifies

${ }^{27}$ Aleksandra Golubović, „Filozofija odgoja“, Riječki teološki časopis, vol. 36, no. 2, 2010., pp. 614 .

${ }^{28}$ Ibid. pp. 621. 
when he says: „there is often a view that it is not the task of the school to educate or to exert an educational influence on, for example, students because education is everyone should bring from home." 29

The goal of education is the comprehensiveness of the various educational functions. If the educator educates only for the purpose of intellectual education and neglects all other education (moral, physical, etc.), then this activity cannot be called education. Both the educator and the student participate in education, and during the educational activity, a special relationship develops between them. Education is determined by what the teacher gives and what the student is capable of spontaneously accepting. Contemporary thinking about education says that education is only possible as two-way communication between educators and students, which will meet their basic human needs, this means that education in its essence is always self-education and that it opens new possibilities not only for the teacher but also for his students. Namely, the educator indirectly creates the conditions for his development, since both the teacher and the student grow together in the educational process.

Education is the duty and obligation of adults: parents, educators, the state, the church, and the elderly in general. In this regard, Bezić claims: "in order for the family, school, professional, social and religious upbringing to bear fruit, all forms of upbringing must work in harmony. Otherwise, not only will there be no success, but there can be severe conflicts and even an educational disaster." ${ }^{30}$ Further, Resić states: "When a young human being comes into the world it is so weak and helpless that without the care and care of adults it would not be possible to sustain itself in life, nor to acquire the characteristics that characterize a human being as a social and moral being. With the concern and care of adults to develop the young man, we encounter in various forms since the creation of man and humankind. In this constant striving for the realization of consistently pedagogical objectives encountered the difficulties, and to observe that the same means and methods of educational activity did not give the same results, as encouraged

\footnotetext{
${ }^{29}$ Ibid. pp. 612.

30 Živan Bezić, »Je li odgoj potreban?«, Crkva u svijetu: teološki časopis,vol. 23, no. 1, 1988., pp. 24.
} 
educators to reflect on educational activities, however, posed the question what is the power of education and what are the boundaries of education?",31

Education is both a need and a natural right of every individual, which means that it is the duty and obligation of society to provide that education. The concern and care of adults for the development of a young man provide for specific material and emotional assumptions that are essential for the child's physical and psychological development, as well as the preconditions for early childhood education. Adults must guide the child, but gradually - as he grows up and can understand - we release the need to always be with him, to help him, because he must become independent in order to become an active member of a particular society. Care and concern, as well as many years of encouragement and help in education, are the basis of every human development. Education is neither all-powerful nor powerless, and it has its limits and possibilities. Assuming that inheritance and unfavorable social circumstances do not impose more significant restrictions, education has great potential in building a human personality and in shaping a person. There are generally three ways of viewing education today, and each one looks at education in a specific way: educational optimism - education is omnipotent, without boundaries and the risk of failure, educational pessimism - does not give any importance to education, considering that everything is predetermined and educational realism - trying to find a middle ground between the previous two extreme points of view.

\section{EDUCATIONAL PESSIMISM}

In the 19th century, doubts were raised about the effectiveness of educational efforts, the so-called educational pessimism. For educational pessimists, heritage theorists, education makes no sense. They consider education to be an unnecessary activity because the inherited cannot be further influenced.

${ }^{31}$ Idris Resić, Moć i granice odgoja, http://majkaidijete.ba/savjeti/pedagogija/ item/2442-moc-i-granice-odgoja, accessed 10. february 2020. 
Živan Bezić writes about it: "regularly, all educational efforts remain fruitless. Even if it achieves little success, it is so insignificant and short-lived that it is not worth mentioning. The inherent factors inherent in human nature are stronger than all external influences. Man is inherently irresistible. As it is born, it remains so all its life. Correct upbringing, as the inner transformation of man, is not possible." 32

Bezić further states: "educational pessimism has always existed. The philosophical justification was given to him by the German philosopher Arthur Schopenhauer. For him, life and existence are nothing but pain, and the dream of happiness and prosperity is a delusion. The whole world is the appearance of some blind will, which no one, especially the weak (and almost all of us), can resist. Bad characters are irreparable." ${ }^{33}$ Schopenhauer thinks that "an evil man can be educated by lessons to be only more cautious and cunning, but not different." 34 As Arthur Schopenhauer's theory is strongly influenced by the Indian Buddhist outlook on the world, such a reflection on education is not surprising, since Buddhists are among them who doubted the power of upbringing.

Educational pessimism is also supported by Sigmund Freud (1856-1939), founder of psychoanalysis. Its appearance and the development of modern psychology and psychoanalysis will enable the liberation of the subconscious in man. "Freud's psychoanalysis leaves very little room for freedom and upbringing (...) He emphasizes the superiority of the subconscious and the urge over human consciousness (...) Conscious educational measures do little to help." ${ }^{35}$ There is no doubt that Freud's thought conveys the thoughts of Arthur Schopenhauer, who was the first and foremost among contemporary philosophers to deal with the unconscious. Long before Freud claimed that the human psyche rests on the unconscious, which is overcome by urges, lusts, and passions. According to Schopenhauer, primacy gets instinctive and unconscious in

\footnotetext{
32 Živan Bezić, „Isplati li se odgajati?“, Obnovljeni život: časopis za filozofiju $i$ religijske znanosti,vol. 30, no. 6, 1975., pp. 553.

${ }^{33}$ Ibid. pp. 553.

34 Idris Resić, Moć $i$ granice odgoja, http://majkaidijete.ba/savjeti/ pedagogija/item/2442-moc-i-granice-odgoja, 2015. accessed 10. february 2020.

35 Živan Bezić, „Isplati li se odgajati?“, pp. 554.
} 
the construction of the human psyche, and the mind and intellect play a secondary role. ${ }^{36}$ When you consider all this, it is no wonder that Schopenhauer reasonably regarded as the philosophical founder of educational pessimism.

About the consequences of educational pessimism, Bezić says: "the practical consequences of educational pessimism would be terrible, deadly for human and social life. Pessimism paralyzes every spiritual development, and it means educational abdication and resignation. $\mathrm{He}$ would bring us back to the animal stage of development, would lead to the devolution and involution of humankind and humanity." ${ }^{, 37}$ Therefore, we cannot accept a pessimistic stance on education because it goes against the generally accepted facts that not traits are inherited, but only dispositions, while abilities, willpower and character traits are acquired under the influence of primary dispositions and external factors. Namely, educational pessimists overemphasize internal factors of personality, neglecting the influence of external factors (family, school, society, culture, etc.). Indeed, it is worth raising because man is a being that can and should be raised. How successful we will be in education depends on many factors, including our hard work. Besides, student opportunities should be optimally perceived and encouraged.

Due to possible problems, the teacher cannot only give up because of doubt about the student's capabilities. There must be no place for pessimism and expression of powerlessness in the educational process. It is easiest to attribute the failure to the irreparable student nature, thus avoiding responsibility for the failure of the educational process. The key is to understand that there are no hopeless situations and there is no problem that the teacher should give up on believing in the success of the educational process.

\footnotetext{
${ }^{36}$ Arthur Schopenhauer, The world as a will and representation, The Falcon's Wing Press. Indian Hills 1958, pp. 142.

37 Živan Bezić, „Isplati li se odgajati?“, pp. 555.
} 


\section{CONCLUSION}

Under the auspices of Arthur Schopenhauer, two unusual geniuses grew up: Friedrich Nietzsche and Sigmund Freud. It is indisputable that through them, he exercised enormous influence over many philosophers of life, existentialists, psychoanalysts, and writers through his philosophical considerations. In Arthur Schopenhauer's philosophy, will is the basis of everything, the basis of reality. The will is not the cause of the phenomena, but the phenomena are different forms of manifestation of the will. Will is eternally unsatisfied and therefore, life is endless suffering. People are constantly in a state of need, so when they are not fulfilled, dissatisfaction ensues. If the needs are met, dissatisfaction will nevertheless emerge at some later point for some new reason. Due to the lack of meaning of life, man is inherently unhappy. He can temporarily overcome suffering by compassion for others, by dedicating himself to art, and the only real cure is asceticism. This type of thinking was the basis of Schopenhauer's pessimism. Friedrich Nietzsche also advocated this. The only thing that made Nietzsche somewhat different from Schopenhauer was that he did not deny life and its significance - for Nietzsche, sadness is an integral part of happiness on the path to Übermensch. Schopenhauer's dark and pessimistic will to live will turn Nietzsche into a creative and optimistic will to power. It introduces the will to power as the principle of setting new values. New values according to Nietzsche, need to be drawn from life, and life itself is the highest value. Life is superior to everything: education, religion and philosophy. Nietzsche, in Schopenhauer's essay as an educator, stands up against the philosophy of the past and accuses her of forging reality.

Furthermore, he sharply criticizes the former value system of German culture. He is committed to breaking down old values and creating new ones. In this sense, he introduces the idea of the Übermensch who is to inherit the present weak man poisoned by existing value systems. It is a man who is capable of rejecting existing morality, religion, state, and himself to create values of his existence that enable him to become a completely free and independent man. Nietzsche warns us that we must not fall into the trap and subordinate the educational 
process to the authorities. State structures are aimed at fulfilling current ideologies, transforming educators into obedient servants and officials of government.

Furthermore, man is by his nature a creative creator only if that creativity is free and following his nature, and not following the aims of society. The content of education is human, and thus the art of education in its essence must aim at the well-being of each individual. All those who wish to engage in education take responsibility for human life, so every modern educator should reflect the philosophy of education. From all of the above, it follows that educational pessimism has no place in the educational process.

\section{BIBLIOGRAPHY}

Batovanja, Vesna, „Škola filozofa“, Studia lexicographica: časopis za leksikografiju i enciklopedistiku, vol. 8, no. 1(14), 2014., pp. 137-147.

Bezić, Živan, „Isplati li se odgajati?“, Obnovljeni život: časopis za filozofiju $i$ religijske znanosti, vol. 30, no. 6, 1975., pp. 553-560.

Bezić, Živan, „Je li odgoj potreban?“, Crkva u svijetu: teološki časopis, vol. 23, no. 1, 1988., pp. 17-25.

Frelih, Jasenka, „Utjecaj Arthura Schopenhauera na književnost i umjetnost“, Nova prisutnost: časopis za intelektualna i duhovna pitanja, vol. XI, no. 1, 2013., pp. 57-72.

Golubović, Aleksandra, „Filozofija odgoja“, Riječki teološki časopis, vol. 36, no. 2, 2010., pp. 609-624.

Kelam, Ivica; Segedin Vučić Jasminka, „The Applicability of the Socrates Method of Education in Education Today“, Pannoniana, vol. 3, no. 1-2, 2019.

Kopić, Mario, Etičar milosrđa, https://pescanik.net/eticar-milosrda/

Nietzsche, Friedrich, Untimely Meditations, Cambridge University Press, Cambridge 1997.

Resić, Idris, »Moć i granice odgoja«, http://majkaidijete.ba/savjeti/ pedagogija/item/2442-moc-i-granice-odgoja,

Schopenhauer, Arthur, Sämtliche Werke, Paul Deussen (ed.), München 1911.

Schopenhauer, Arthur, The world as a will and representation, The Falcon's Wing Press, Indian Hills 1958. 
Sunajko, Goran, „Genij nasuprot talentu - umjetnost nasuprot estetici: bit Schopenhauerove estetike“, Studia lexicographica: časopis za leksikografiju i enciklopedistiku, vol. 11, no. 21, 2017.., pp. 61-74.

Udruga za promicanje filozofije Filozofija.org, »Arthur Schopenhauer (1788. 1860.) «, https://www.filozofija.org/wpcontent/uploads/Povijest_fil.org/suvremen a_1_pdf/Schopenhauer-final.pdf.

IVICA KELAM, LUKA RAŠIĆ

Sveučilište J. J. Strossmayera u Osijeku, Fakultet za odgojne i obrazovne znanosti, Hrvatska

\section{UTICAJ ŠOPENHAUEROVIH I NIČEOVIH FILOZOFSKIH MISLI NA FILOZOFIJU ODGOJA I ODGOJNI PESIMIZAM}

Sažetak: U ovom radu dan je svojevrstan prikaz promišljanja odgoja i obrazovanja dvojice glasovitih filozofa zapadnoeuropske kulture, Arthura Schopenhauera i Friedricha Nietzschea. Ono što povezuje njihovu filozofiju odgoja i obrazovanja jest težnja za što potpunijim oblikovanjem čovjeka.

Nietzsche je veliki pristalica Schopenhauerova shvaćanja filozofije kao filozofije života. No, dok je Schopenhauer ostao zatočen u svijetu pesimizma, Nietzsche je pesimističku viziju svijeta prevladao likom kreativnog umjetnika koji stalno pokreće život, uživajući u vlastitoj umjetnosti življenja. Ono što im je zajedničko, to je ekstremni individualizam - shvaćanje filozofije kao oslobađanje unutarnjega života.

Arthur Schopenhauer pojmio je čovjeka kao biće volje koje podliježe zakonitostima prirode i nižih razina čovječnosti, volji i strastima. Friedrich Nietzsche pojmio ga je kao biće volje k moći, naglasivši moć onog nagonskog i iracionalnog. Dok je Schopenhauer dao pesimističku viziju čovjeka u vlasti neutažive volje za život, Nietzsche je dao nihilističku sliku svijeta, rušenje starih vrijednosti i njihovo dotrajavanje. Nihilist je, po Nietzscheovu mišljenju, netko kojemu se sve pojavljuje kao besmisleno i uzaludno.

Arthur Schopenhauer izvršio je važan utjecaj, ne samo na Friedricha Nietzschea, već i na neke druge velikane svoga doba, no oni većinom nisu podupirali njegovu filozofiju u cjelini. Razumijevanje svijeta na Schopenhauerov način zaživjelo je, u pravom smislu riječi, tek krajem 19. stoljeća i kasnije, upravo 
zahvaljujući Friedrichu Nietzscheu. To je bilo doba u kojem su se društvene znanosti konačno počele razvijati odvojeno, ali su jedna drugu nadopunjavale. Zbog njihova međudjelovanja bilo je i moguće da Schopenhauer, a preko njega i Nietzsche, imaju tako velik utjecaj na europski duhovni život.

Ključne riječi: filozofija, odgoj, odgojni pesimizam, Arthur Schopenhauer, Friedrich Nietzsche

Primljeno: 11.2.2020.

Prihvaćeno: 6.5.2020. 